\title{
Synthesis, Characterization and Photophysical Properties of ESIPT Reactive Triazine Derivatives
}

\author{
Marcelo D. Kuplich, Fábio S. Grasel, Leandra F. Campo, \\ Fabiano S. Rodembusch and Valter Stefani*
}

\author{
Laboratório de Novos Materiais Orgânicos, Instituto de Química, Universidade Federal do \\ Rio Grande do Sul, Av. Bento Gonçalves 9500, CP 15003, 91501-970 Porto Alegre-RS, Brazil
}

\begin{abstract}
Uma série de quatro compostos fotoativos derivados da triazina foi obtida a partir da substituição nucleofílica aromática no cloreto cianúrico. Os compostos foram caracterizados por espectroscopia de infravermelho (IR) e ressonância magnética nuclear (NMR de ${ }^{1} \mathrm{H}$ e ${ }^{13} \mathrm{C}$ ), além de espectrometria de massas de alta resolução (HRMS MALDI). A espectroscopia de absorção na região do UV-Vis e a emissão de fluorescência (no estado sólido e em solução) foram também utilizadas para estudar o comportamento fotofísico destes compostos. Os derivados obtidos são fluorescentes na região do azul-laranja por um mecanismo de transferência protônica intramolecular no estado excitado e apresentam um grande deslocamento de Stokes $\left(6365-10290 \mathrm{~cm}^{-1}\right)$. Os derivados sintetizados neste trabalho reagiram com sucesso com fibras de celulose para dar novos compostos celulósicos fluorescentes.
\end{abstract}

Four new reactive fluorescent triazine derivatives were obtained from nucleophilic aromatic substitution of cyanuric chloride. The compounds were characterized by infrared spectroscopy (IR), nuclear magnetic resonance $\left({ }^{13} \mathrm{C}\right.$ and $\left.{ }^{1} \mathrm{H} \mathrm{NMR}\right)$ and high resolution mass spectrometry (HRMS MALDI). UV-Vis and steady-state fluorescence (in solution and in solid state) spectroscopies were also applied to characterize the photophysical behavior. The dyes are fluorescent by an intramolecular proton transfer mechanism (ESIPT) in the blue-orange region, with a large Stokes shift between $6365-10290 \mathrm{~cm}^{-1}$. The fluorescent cyanuric derivatives could successfully react with cellulose fibers to give new fluorescent cellulosic materials.

Keywords: triazine, benzazoles, cyanuric chloride, ESIPT, reactive dyes, cellulose

\section{Introduction}

The 2,4,6-trichloro-1,3,5-triazine (TCT), so-called cyanuric chloride, is an important triazine derivative and a well-known precursor in organic synthesis. ${ }^{1-11}$ This precursor have become a very attractive field of research by virtue of the applications that can be envisaged with the obtained products, such as polymers, ${ }^{12-15}$ non-linear optical materials ${ }^{16-18}$ and new photoactive materials. ${ }^{19-23} \mathrm{~A}$ particular interest has been reported on the use of cyanuric chloride in reactive dyes ${ }^{24}$ since they are able to bond hydroxy groups from the cellulose and amino or thiol from proteins or polyamides. ${ }^{25}$ In this way, several structures have been reported using TCT as molecular link between the chromophore or fluorescent dye and the organic matrix. ${ }^{26-29}$

On the other hand, the benzazoles often show a large Stokes shift due to an excited state intramolecular proton

\footnotetext{
*e-mail: vstefani@iq.ufrgs.br
}

transfer (ESIPT) mechanism. ${ }^{30}$ This phenomenon has widespread implications as optical sensors, ${ }^{31-34}$ photoactive hybrid materials ${ }^{35,36}$ and new polymeric materials. ${ }^{37}$

Despite of the great attention of ESIPT-exhibiting dyes and the versatile applications of cyanuric chloride in organic synthesis as starting material to produce dyes, herbicides, polymers and compounds of pharmaceutical interest, ${ }^{38}$ this paper presents the synthesis and the photophysical characterization of new ESIPT reactive dyes based on the triazine moiety. Additionally, the obtained derivatives were tested as fluorophores for cellulosic materials.

\section{Experimental}

Materials and methods

2,4,6-Trichloro-1,3,5-triazine were purchased from ACROS Organics. All the solvents were used as received or 

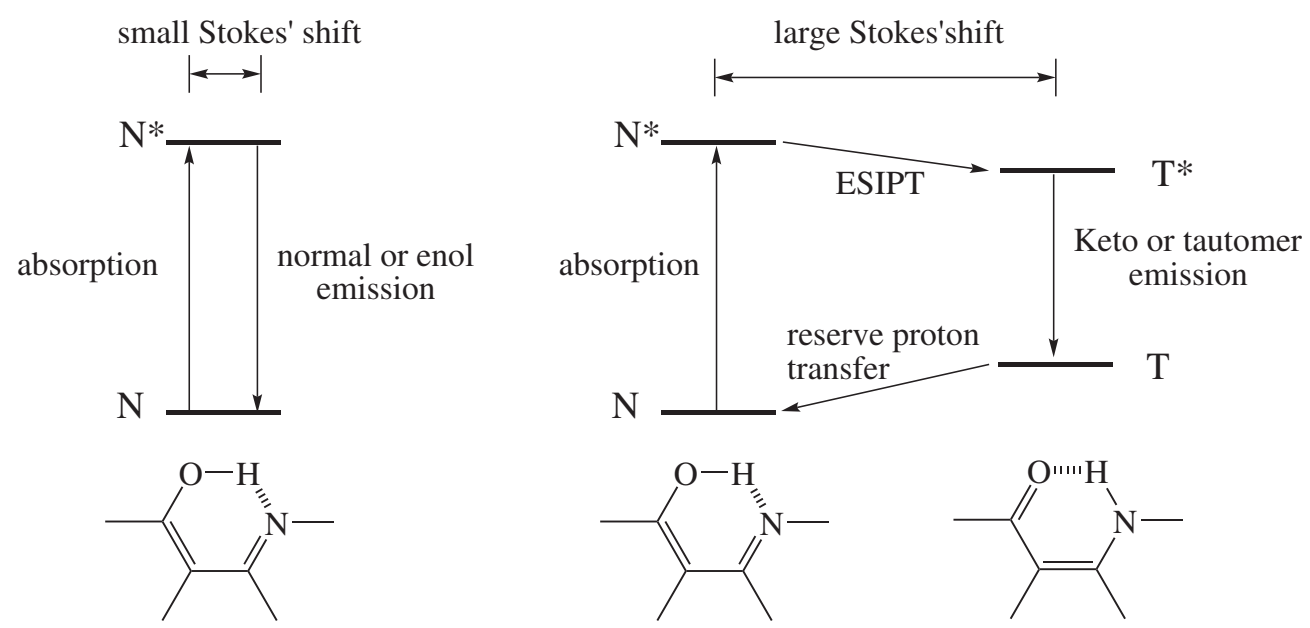

Figure 1. Photophysical pathways from ESIPT-exhibiting dyes: normal (or enol) emission (left) and ESIPT (or tautomer) emission (right).

purified using standard procedures. Spectroscopic grade solvents (Merck) were used for fluorescence and UV-Vis measurements. Melting points (mp) were measured with a Gehaka PF 1000 apparatus and are uncorrected. Infrared spectra were recorded on a Shimadzu FTIR8300 in $\mathrm{KBr}$ pellets. ${ }^{1} \mathrm{H}$ and ${ }^{13} \mathrm{C}$ NMR spectra were performed on a VARIAN INOVA YH300 using tetramethylsilane (TMS) as the internal standard and DMSO- $d_{6}$ (Aldrich) as the solvent at room temperature. UV-Vis absorption spectra were performed on a Shimadzu UV-1601PC spectrophotometer. Steady state fluorescence spectra were measured with a Hitachi spectrofluorometer model F-4500. Spectrum correction was performed to enable measuring a true spectrum by eliminating instrumental response such as wavelength characteristics of the monochromator or detector using Rhodamine B as a standard (quantum counter). For the photophysical measurements in the solid state, the photoactive cellulose fibers were measured in bulk using a solid sample holder. In this device, the light beam was irradiated to the sample at an angle of $c a .30^{\circ}$, and the light beam from the sample was reflected at an angle of $c a$. $-60^{\circ}$. All experiments were performed at room temperature in a concentration of $10^{-6} \mathrm{~mol} \mathrm{~L}^{-1}$. HRMS spectra were recorded with a Bruker Reflex III spectrometer.

\section{Synthesis of the triazine derivatives}

The dyes 1a-d were prepared using a previously described methodology. ${ }^{39}$ The triazine benzazole derivatives 3a-d were prepared according to Figure 2. In a typical experiment, an equimolar amount of the amino derivative 1a-d and 2,4,6-trichloro-1,3,5-triazine were both dissolved in acetone. The dye solution was added dropwise into the triazine solution, cooled up to $0{ }^{\circ} \mathrm{C}$, followed by addition of a $\mathrm{Na}_{2} \mathrm{CO}_{3}$ solution (10\%). The final solution was mixed for $1 \mathrm{~h}$. The crude product, which precipitates, was washed with water and cold acetone and dried at room temperature. The purification was made by recristallization using dioxane/water. The final yields were from 70 to $96 \%$.

2-[4'-(N-4,6-Dichloro-1,3,5-triazin-2-yl)-2'-hydroxyphenyl] benzoxazole (3a)

Yield: 70\%; mp $>350{ }^{\circ} \mathrm{C}$; IR $(\mathrm{KBr}) v_{\max } / \mathrm{cm}^{-1} 3296$ $v(\mathrm{~N}-\mathrm{H}), 3059 v_{\text {arom }}(\mathrm{C}-\mathrm{H}), 1618 v(\mathrm{C}=\mathrm{N}), 1537$ and 1501 $v_{\text {arom }}(\mathrm{C}=\mathrm{C}), 1238 v(\mathrm{Ar}-\mathrm{O}), 1188 v(\mathrm{C}-\mathrm{N}), 748 v(\mathrm{C}-\mathrm{Cl})$; ${ }^{1} \mathrm{H}$ NMR (300 MHz, DMSO- $d_{6}$ ) $\delta / \mathrm{ppm} 10.96(\mathrm{~s}, 1 \mathrm{H}$, $\mathrm{OH}), 7.98\left(\mathrm{~d}, 1 \mathrm{H}, \mathrm{H}_{6}, J_{o} 8.7 \mathrm{~Hz}\right), 7.88-7.76\left(\mathrm{~m}, 2 \mathrm{H}, \mathrm{H}_{4}\right.$ and $\left.\mathrm{H}_{7}\right), 7.66\left(\mathrm{~d}, 1 \mathrm{H}, \mathrm{H}_{3}, J_{m} 2.0 \mathrm{~Hz}\right), 7.50-7.38(\mathrm{~m}, 2 \mathrm{H}$, $\mathrm{H}_{5}$ and $\left.\mathrm{H}_{6}\right), 7.21\left(\mathrm{dd}, 1 \mathrm{H}, \mathrm{H}_{5}, J_{m} 2.0 \mathrm{~Hz}\right.$ and $\left.J_{o} 8.7 \mathrm{~Hz}\right)$; ${ }^{13} \mathrm{C}$ NMR (75.4 MHz, DMSO- $\left.d_{6}\right) \delta /$ ppm $162\left(\mathrm{C}_{2}\right), 158$ $\left(\mathrm{C}_{4^{\prime} \mathrm{a}}\right), 154\left(\mathrm{C}_{4^{\prime} \mathrm{b}}\right.$ and $\left.\mathrm{C}_{4^{\prime} \mathrm{c}}\right), 153\left(\mathrm{C}_{2^{\prime}}\right), 149\left(\mathrm{C}_{8}\right), 142\left(\mathrm{C}_{4^{\prime}}\right)$, $139\left(\mathrm{C}_{9}\right), 128\left(\mathrm{C}_{5}\right), 126\left(\mathrm{C}_{6}\right.$ or $\left.\mathrm{C}_{6}\right), 125\left(\mathrm{C}_{6}\right.$, or $\left.\mathrm{C}_{6}\right), 119$ $\left(\mathrm{C}_{4}\right), 112\left(\mathrm{C}_{3}\right.$, or $\left.\mathrm{C}_{7}\right), 111\left(\mathrm{C}_{7}\right.$ or $\left.\mathrm{C}_{3}\right), 108\left(\mathrm{C}_{5},\right), 106\left(\mathrm{C}_{1}\right)$; exact mass: $373.0133 \mathrm{~g} \mathrm{~mol}^{-1}$; the exact molecular mass for $\mathrm{C}_{16} \mathrm{H}_{9} \mathrm{Cl}_{2} \mathrm{~N}_{5} \mathrm{O}_{2} \mathrm{~m} / \mathrm{z}, 373.012$ was found by HRMS (MALDI).

2-[4'-(N-4,6-Dichloro-1,3,5-triazin-2-yl)-2'-hydroxyphenyl] benzothiazole $(\mathbf{3 b})$

Yield: $80 \%$; $\mathrm{mp}>350{ }^{\circ} \mathrm{C}$; IR $(\mathrm{KBr}) v_{\max } / \mathrm{cm}^{-1} 3331$ $v(\mathrm{~N}-\mathrm{H}), 3069 v_{\text {arom }}(\mathrm{C}-\mathrm{H}), 1612 v(\mathrm{C}=\mathrm{N}), 1566$ and 1481 $v_{\text {arom }}(\mathrm{C}=\mathrm{C}), 1238 v(\mathrm{Ar}-\mathrm{O}), 1186 \mathrm{v}(\mathrm{C}-\mathrm{N}), 752 v(\mathrm{C}-\mathrm{Cl})$; ${ }^{1} \mathrm{H}$ NMR $\left(300 \mathrm{MHz}, \mathrm{DMSO}-d_{6}\right) \delta / \mathrm{ppm} 11.19$ (s, 1H, OH), $8.24\left(\mathrm{~d}, 1 \mathrm{H}, \mathrm{H}_{3}, J_{m} 2.7 \mathrm{~Hz}\right), 7.94-7.80\left(\mathrm{~m}, 2 \mathrm{H}, \mathrm{H}_{4}\right.$ and $\left.\mathrm{H}_{7}\right)$, $7.72\left(\mathrm{dd}, 1 \mathrm{H}, \mathrm{H}_{5}, J_{m} 2.7 \mathrm{~Hz}\right.$ and $\left.J_{o} 9.0 \mathrm{~Hz}\right), 7.54-7.42(\mathrm{~m}$, $2 \mathrm{H}, \mathrm{H}_{5}$ and $\left.\mathrm{H}_{6}\right), 7.19\left(\mathrm{~d}, 1 \mathrm{H}, \mathrm{H}_{6}, J_{o} 9.0 \mathrm{~Hz}\right) ;{ }^{13} \mathrm{C} \mathrm{NMR}$ $\left(75.4 \mathrm{MHz}\right.$, DMSO- $\left.d_{6}\right) \delta / \mathrm{ppm} 170\left(\mathrm{C}_{2}\right), 164\left(\mathrm{C}_{4^{\prime} \mathrm{a}}\right), 162$ $\left(\mathrm{C}_{4^{\prime} \mathrm{b}}\right.$ and $\left.\mathrm{C}_{4^{\prime} \mathrm{c}}\right), 155\left(\mathrm{C}_{2^{\prime}}\right), 149\left(\mathrm{C}_{9}\right), 140\left(\mathrm{C}_{4^{\prime}}\right), 129\left(\mathrm{C}_{8}\right)$, 
<smiles>[X]c1nc2ccccc2[nH]1</smiles>

(1a) $\mathrm{X}=\mathrm{O}$

(1b) $X=S$

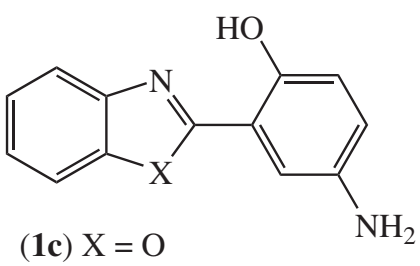

(1d) $X=S$<smiles>Clc1nc(Cl)nc(Cl)n1</smiles>

2<smiles>Clc1nc(Cl)nc(Cl)n1</smiles>

$\underset{1 \mathrm{~h}, 0{ }^{\circ} \mathrm{C}}{\stackrel{\text { acetone }}{\longrightarrow}}$

(3d) $X=S$<smiles>[Y][Y16]#[SH]=O</smiles><smiles>[X]c1ccccc2nc(-c3cc(Nc4nc(Cl)nc(Cl)n4)ccc3O)[Y4](=O):[Y14]1-2</smiles>

Figure 2. Synthesis of the triazine derivatives 3a-d.

$128\left(\mathrm{C}_{4}\right), 126\left(\mathrm{C}_{5}\right.$ or $\left.\mathrm{C}_{6}\right), 125\left(\mathrm{C}_{5}\right.$ or $\left.\mathrm{C}_{6}\right), 121\left(\mathrm{C}_{6}\right), 119$ $\left(\mathrm{C}_{7}\right.$ or $\left.\mathrm{C}_{3}\right), 118\left(\mathrm{C}_{3}\right.$, or $\left.\mathrm{C}_{7}\right), 111\left(\mathrm{C}_{5}\right), 110\left(\mathrm{C}_{1}\right)$; exact mass: $388.9905 \mathrm{~g} \mathrm{~mol}^{-1}$; the exact molecular mass for $\mathrm{C}_{16} \mathrm{H}_{9} \mathrm{Cl}_{2} \mathrm{~N}_{5} \mathrm{OS} m / z 388.990$ was found by HRMS (MALDI).

2-[5'-(N-4,6-Dichloro-1,3,5-triazin-2-yl)-2'-hydroxyphenyl] benzoxazole (3c)

Yield: $83 \%$; $\mathrm{mp}>350{ }^{\circ} \mathrm{C}$; IR $(\mathrm{KBr}) v_{\max } / \mathrm{cm}^{-1} 3302$ $v(\mathrm{~N}-\mathrm{H}), 3065 v_{\text {arom }}(\mathrm{C}-\mathrm{H}), 1616 \mathrm{v}(\mathrm{C}=\mathrm{N}), 1587$ and 1501 $v_{\text {arom }}(\mathrm{C}=\mathrm{C}), 1238 v(\mathrm{Ar}-\mathrm{O}), 1167 \mathrm{v}(\mathrm{C}-\mathrm{N}), 739 \mathrm{v}(\mathrm{C}-\mathrm{Cl})$; ${ }^{1} \mathrm{H}$ NMR $\left(300 \mathrm{MHz}, \mathrm{DMSO}-d_{6}\right) \delta / \mathrm{ppm} 10.98$ (s, $\left.1 \mathrm{H}, \mathrm{OH}\right)$, $8.23\left(\mathrm{~d}, 1 \mathrm{H}, \mathrm{H}_{6}, J_{m} 2.7 \mathrm{~Hz}\right), 7.94-7.84\left(\mathrm{~m}, 2 \mathrm{H}, \mathrm{H}_{4}\right.$ and $\left.\mathrm{H}_{7}\right)$, $7.61\left(\mathrm{dd}, 1 \mathrm{H}, \mathrm{H}_{4}, J_{m} 2.7 \mathrm{~Hz}\right.$ and $\left.J_{o} 9.0 \mathrm{~Hz}\right), 7.54-7.44(\mathrm{~m}$, $2 \mathrm{H}, \mathrm{H}_{5}$ and $\left.\mathrm{H}_{6}\right), 7.17\left(\mathrm{~d}, 1 \mathrm{H}, \mathrm{H}_{3}, J_{o} 9.0 \mathrm{~Hz}\right) ;{ }^{13} \mathrm{C} \mathrm{NMR}$ (75.4 MHz, DMSO- $\left.d_{6}\right) \delta /$ ppm $170\left(\mathrm{C}_{2}\right), 164\left(\mathrm{C}_{4}{ }^{\prime}\right), 162$ $\left(\mathrm{C}_{4^{\prime} \mathrm{b}}\right.$ and $\left.\mathrm{C}_{4{ }^{\prime} \mathrm{c}}\right), 155\left(\mathrm{C}_{2},\right), 149\left(\mathrm{C}_{8}\right), 140\left(\mathrm{C}_{9}\right), 129\left(\mathrm{C}_{4}\right), 126$ $\left(\mathrm{C}_{5}\right.$ or $\left.\mathrm{C}_{6}\right), 125\left(\mathrm{C}_{5}\right.$ or $\left.\mathrm{C}_{6}\right), 121\left(\mathrm{C}_{4}\right), 119\left(\mathrm{C}_{6}\right.$, or $\left.\mathrm{C}_{3}\right), 118$ $\left(\mathrm{C}_{3}\right.$, or $\left.\mathrm{C}_{6}\right), 111\left(\mathrm{C}_{7}\right), 110\left(\mathrm{C}_{1}\right)$; exact mass: $373.0133 \mathrm{~g} \mathrm{~mol}^{-1}$; the exact molecular mass for $\mathrm{C}_{16} \mathrm{H}_{9} \mathrm{Cl}_{2} \mathrm{~N}_{5} \mathrm{O}_{2} \mathrm{~m} / \mathrm{z} 373.012$ was found by HRMS (MALDI).

2-[5'-(N-4,6-Dichloro-1,3,5-triazin-2-yl)-2'-hydroxyphenyl] benzothiazole $(\mathbf{3 d})$

Yield: $96 \%$; $\mathrm{mp}>350{ }^{\circ} \mathrm{C}$; IR $(\mathrm{KBr}) \mathrm{v}_{\max } / \mathrm{cm}^{-1} 3285$ $v(\mathrm{~N}-\mathrm{H}), 3063 \mathrm{v}_{\text {arom }}(\mathrm{C}-\mathrm{H}), 1556$ and $1501 \mathrm{v}_{\text {arom }}(\mathrm{C}=\mathrm{C}), 1238$ v(Ar-O), $1198 v(\mathrm{C}-\mathrm{N}), 758 \mathrm{v}(\mathrm{C}-\mathrm{Cl}) ;{ }^{1} \mathrm{H}$ NMR $(300 \mathrm{MHz}$, DMSO- $d_{6}$ ) $\delta /$ ppm 11.09 (s, $\left.1 \mathrm{H}, \mathrm{OH}\right) ; 8.41$ (d, 1H, $\mathrm{H}_{6}$, $\left.J_{m} 2.7 \mathrm{~Hz}\right) .8 .15\left(\mathrm{~d}, 1 \mathrm{H}, \mathrm{H}_{4}\right.$ or $\left.\mathrm{H}_{7}\right), 8.05\left(\mathrm{~d}, 1 \mathrm{H}, \mathrm{H}_{7}\right.$ or $\left.\mathrm{H}_{4}\right)$, $7.60\left(\mathrm{dd}, 1 \mathrm{H}, \mathrm{H}_{4}, J_{m} 2.7 \mathrm{~Hz}\right.$ and $\left.J_{o} 9.0 \mathrm{~Hz}\right), 7.54(\mathrm{t}, 1 \mathrm{H}$, $\mathrm{H}_{5}$ or $\mathrm{H}_{6}$ ), 7.45 (t, $1 \mathrm{H}, \mathrm{H}_{6}$ or $\mathrm{H}_{5}$ ), $7.13\left(\mathrm{~d}, 1 \mathrm{H}, \mathrm{H}_{3}, J_{o} 9.0 \mathrm{~Hz}\right)$;
${ }^{13} \mathrm{C}$ NMR (75.4 MHz, DMSO- $\left.d_{6}\right) \delta / p p m ~ 170\left(\mathrm{C}_{2}\right), 169$ $\left(\mathrm{C}_{5}{ }^{\prime}\right), 164\left(\mathrm{C}_{5}{ }^{\prime}\right.$ b or $\left.\mathrm{C}_{5}{ }^{\prime} \mathrm{c}\right), 154\left(\mathrm{C}_{2},\right), 151\left(\mathrm{C}_{9}\right), 135\left(\mathrm{C}_{5},\right)$, $129\left(\mathrm{C}_{8}\right), 127\left(\mathrm{C}_{5}\right.$ or $\left.\mathrm{C}_{6}\right), 127\left(\mathrm{C}_{5}\right.$ or $\left.\mathrm{C}_{6}\right), 125\left(\mathrm{C}_{4}\right), 122$ $\left(\mathrm{C}_{7}\right.$ or $\left.\mathrm{C}_{4}\right), 122\left(\mathrm{C}_{4}\right.$, or $\left.\mathrm{C}_{7}\right), 122\left(\mathrm{C}_{6}\right), 118\left(\mathrm{C}_{1}\right), 117\left(\mathrm{C}_{3}\right)$; exact mass: $388.9905 \mathrm{~g} \mathrm{~mol}^{-1}$; the exact molecular mass for $\mathrm{C}_{16} \mathrm{H}_{9} \mathrm{Cl}_{2} \mathrm{~N}_{5} \mathrm{OS} \mathrm{m} / z 388.989$ was found by HRMS (MALDI).

\section{Dye incorporation into the cellulose fibers}

In a typical experiment, the cellulose was stained by addition of the cotton $(100 \mathrm{mg})$ into an aqueous solution of $\mathrm{Na}_{2} \mathrm{SO}_{4}\left(0.05 \mathrm{~mol} \mathrm{~L}^{-1}\right)$ and $0.2 \mathrm{ml}$ of sodium hydroxide $(10 \% \mathrm{~m} / \mathrm{v})$ followed by the addition of the fluorescent dye (1 $\mathrm{mg} \mathrm{mL}^{-1}$ in DMSO). The reaction mixture was allowed to react for $1 \mathrm{~h}$ at $45^{\circ} \mathrm{C}$. The crude stained cotton was washed several times with water, followed by Soxhlet extraction using acetone for $3 \mathrm{~h}$ in order to remove the unreacted fluorescent dye. The percentages of the triazine dye incorporation were evaluated using the absorption data from UV-Vis spectroscopy. Since the extinction coefficients of the dyes are well-known, the percentages of the triazine dye incorporation, which were from 80 up to $95 \%$, were determined by the reactive dye extinction coefficients at a specific wavelength from UV-Vis data of the washing solutions (Lambert-Beer Law).

\section{Results and Discussion}

Photophysical characterization

Figures 3 and 4 show the normalized UV-Vis absorption spectra of the triazine derivatives (3a-d) in 


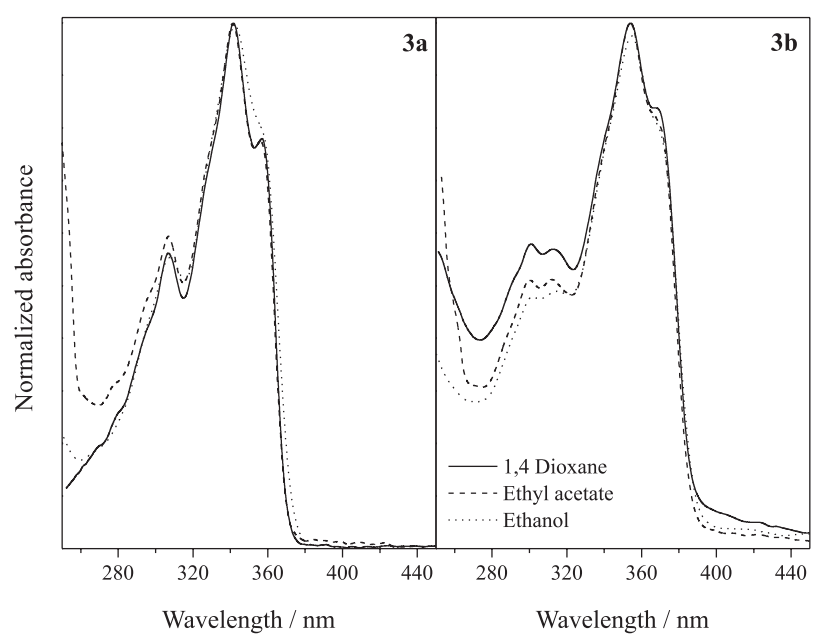

Figure 3. Normalized absorption spectra of 3a-b.

1,4-dioxane, ethyl acetate and ethanol. The relevant UV-Vis data are summarized in Table 1.

An absorption band maxima $\left(\lambda_{\max }\right)$ located around 358 and $368 \mathrm{~nm}$ (with molar extinction coefficient values $\left(\varepsilon_{\max }\right)$ in agreement with $\pi-\pi^{*}$ transitions) could be observed for the derivatives $\mathbf{3} \mathbf{a}$ and $\mathbf{3} \mathbf{b}$, respectively. A small solvatochromic effect could be observed for these dyes $(c a .4 \mathrm{~nm})$. The absorption maximum of $\mathbf{3 b}$ is red shifted in relation to $\mathbf{3 a}$, which can be explained by the better electron delocalization. This is allowed by the sulfur atom in relation to the oxygen. The same photophysical behavior was observed for derivatives $\mathbf{3 c}$ and $\mathbf{3 d}$, with an absorption maximum located $c a .338$ and $352 \mathrm{~nm}$, respectively.

The intense absorption bands observed at $280-310 \mathrm{~nm}$ for derivatives 3c-d indicate that the substitution in the phenolic ring is decisive for the photophysics of these dyes and can be associated to a difference of planarity of the dyes. ${ }^{40} \mathrm{~A}$ non-planar structure does not allow a

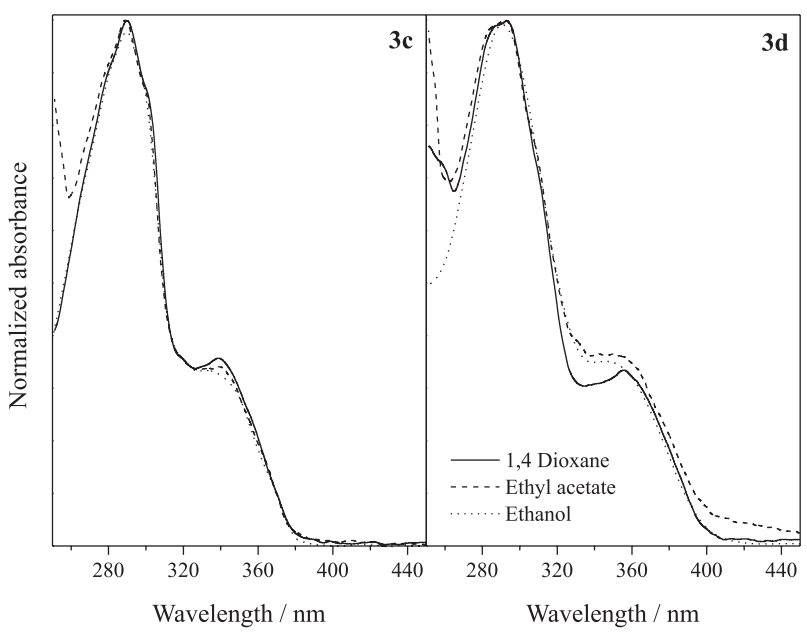

Figure 4. Normalized absorption spectra of 3c-d.

more effective electronic delocalization among the two $\pi$ systems (phenolic and benzoxazolic rings). In this way, the para derivative showed to be less planar than their metha analogue. The intense bands at $280-310 \mathrm{~nm}$ are related to the oxazole chromophore. ${ }^{41,42}$ The difference between the molecular planarity of these dyes is confirmed taking the molar extinction coefficient values into account (see Table 1). A less planar structure usually presents a lower probability for the $\pi-\pi^{*}$ transition.

Figures 5 and 6 present the normalized fluorescence emission spectra of these dyes. The curves were obtained using the absorption maxima as the excitation wavelengths. The relevant data are also summarized in Table 1.

The derivatives 3a-d present one main band located at ca. 471, 506, 514 and $546 \mathrm{~nm}$, respectively. In solution, these dyes are fluorescent in the blue-green (3a-b) and green-yellow (3c-d) regions. The fluorescence emission bands are ascribed to the ESIPT band ( $\mathrm{T}^{*}$ emission) since

Table 1. Relevant UV-Vis data of the triazine derivatives 3a-d

\begin{tabular}{|c|c|c|c|c|c|}
\hline Dye & Solvent & $\lambda_{\text {abs }} / \mathrm{nm}$ & $\varepsilon_{\max } \times 10^{4} /\left(\mathrm{mol}^{-1} \mathrm{~L} \mathrm{~cm}^{-1}\right)$ & $\lambda_{\mathrm{em}} / \mathrm{nm}$ & $\Delta \lambda_{\mathrm{ST}} /\left(\mathrm{nm} / \mathrm{cm}^{-1}\right)$ \\
\hline \multirow[t]{3}{*}{$3 \mathbf{a}$} & 1,4-dioxane & 358 & 4.4 & 474 & $116 / 6836$ \\
\hline & ethyl acetate & 356 & 3.1 & 471 & $115 / 6859$ \\
\hline & ethanol & 360 & 5.6 & 467 & $107 / 6365$ \\
\hline \multirow[t]{3}{*}{$3 \mathbf{b}$} & 1,4-dioxane & 370 & 5.2 & 510 & $140 / 7419$ \\
\hline & ethyl acetate & 366 & 4.4 & 505 & $139 / 7520$ \\
\hline & ethanol & 367 & 4.9 & 504 & $137 / 7407$ \\
\hline \multirow[t]{3}{*}{$3 \mathbf{c}$} & 1,4-dioxane & 339 & 1.4 & 515 & $176 / 10081$ \\
\hline & ethyl acetate & 341 & 1.4 & 515 & $174 / 9908$ \\
\hline & ethanol & 335 & 1.3 & 513 & $178 / 10358$ \\
\hline \multirow[t]{3}{*}{ 3d } & 1,4-dioxane & 356 & 1.2 & 547 & 191/9809 \\
\hline & ethyl acetate & 350 & 1.9 & 547 & $197 / 10290$ \\
\hline & ethanol & 350 & 1.1 & 544 & $194 / 10189$ \\
\hline
\end{tabular}




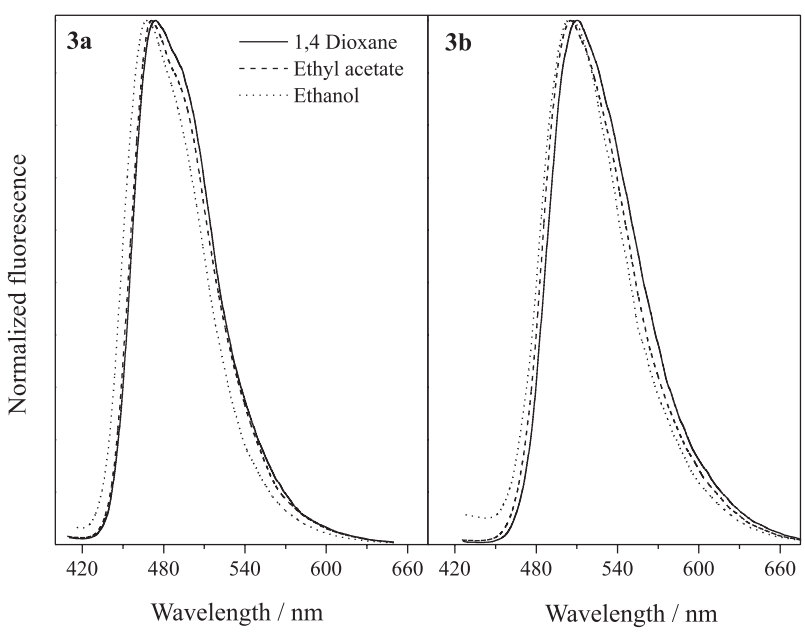

Figure 5. Normalized fluorescence emission spectra of $\mathbf{3 a - b}$.

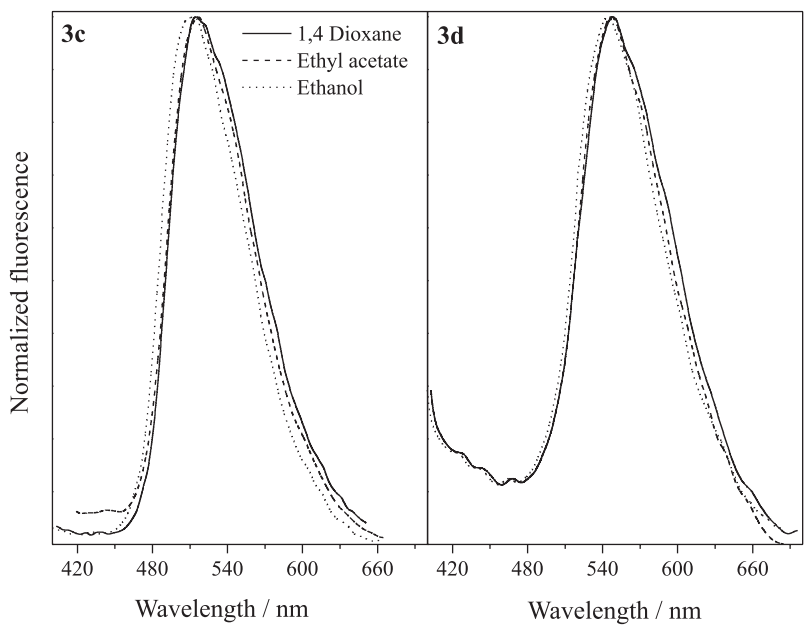

Figure 6. Normalized fluorescence emission spectra of $\mathbf{3 c - d}$.

a Stokes shift higher than $100 \mathrm{~nm}$ could be detected for all dyes. ${ }^{43}$

Figure 7 shows the normalized fluorescence emission spectra in the solid state of the dyes $\mathbf{3 a - d}$, as well as the dyes covalently bounded into the cellulose matrix. The absorption maxima in solution were used as excitation wavelength in the solid state measurements. As already observed in solution, the derivatives 3a-d present one main band located from 459 to $537 \mathrm{~nm}$, which comprises the blue-orange region.

Concerning the location of the fluorescence emission maxima in solution (Table 1), the dyes in the solid state present blue shifted bands (3a: $459 \mathrm{~nm}, \mathbf{3 b}: 508 \mathrm{~nm}$, 3c: $491 \mathrm{~nm}$ and 3d: $536 \mathrm{~nm}$ ), indicating that the studied solvents can better stabilize the keto tautomer in the excited state. Additionally, comparing dyes 3a-c in the solid state and the cellulosic material after the staining process, it can be observed small changes in the fluorescence emission maxima due to the interaction with the cellulose matrix.

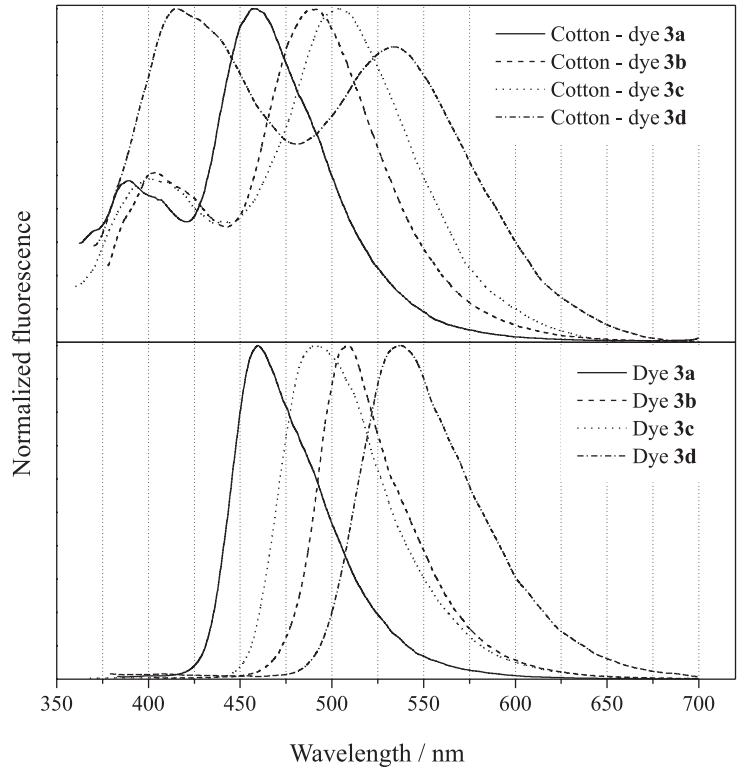

Figure 7. Normalized solid-state fluorescence emission spectra of the derivatives 3a-d (bottom) and covalently bounded into cellulose fibers (top). This measurement treats the fibers in bulk using a solid sample holder with the light beam irradiated to the sample at an angle of $c a .30^{\circ}$, and the light beam from the sample reflected at an angle of $c a .-60^{\circ}$.

However, after the staining process using dye 3d, a dual fluorescence emission can be observed in the cellulose. The band located at higher wavelengths is ascribed to the ESIPT band and, the blue shifted one is ascribed to the normal relaxation ( $\mathrm{N}^{*}$ emission). ${ }^{44}$ This photophysical behavior confirms a conformational equilibrium in the ground state for this dye. Since the hydroxyl moieties in the cellulose matrix could stabilize through intermolecular hydrogen bond, additional conformers can be related to the normal emission. ${ }^{44}$ A pictorial scheme with the inter (left) and intramolecular (right) hydrogen bonds between the ESIPT dye and the cellulose is presented in Figure 8. Although the synthesized triazine dyes present two reactive chlorine atoms, the reactive dye is shown with only one replaced chlorine atom by the cellulose matrix. This is because the used temperature for the incorporation of the triazine derivatives into the cellulose fibers was below the needed temperature to replace the last chlorine atom. ${ }^{24}$

\section{Conclusions}

Four new fluorescent cotton reactive dyes were synthesized, purified and characterized by infrared spectroscopy, nuclear magnetic resonance $\left({ }^{13} \mathrm{C}\right.$ and $\left.{ }^{1} \mathrm{H} N M R\right)$, high resolution mass spectrometry (HRMS MALDI), UV-Vis and steady-state fluorescence spectroscopies (in solution and in the solid state). The triazine derivatives are fluorescent in the blue-orange region with a Stokes shift between $6365-10290 \mathrm{~cm}^{-1}$. The fluorescent cyanuric derivatives could 


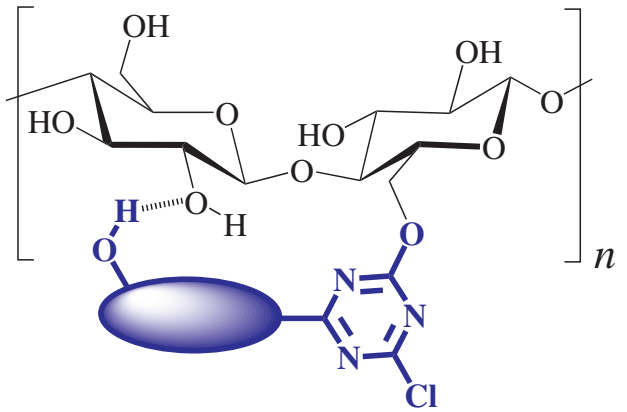

$\begin{array}{ll}\text { UV } & \text { Normal } \\ \text { radiation } & \text { emission }\end{array}$

Figure 8. Scheme of interaction between the ESIPT dyes and the cellulose.

successfully react with cellulose fibers to produce new ESIPT fluorescent cellulosic materials. A dual fluorescence emission could be observed in the stained cotton using the dye $\mathbf{3 d}$, which indicates a conformational equilibrium in solution in the ground state. The emission at long wavelength (ESIPT band) is related to the ESIPT band and, the blue shifted ones are due to conformational forms with a normal relaxation.

\section{Supplementary Information}

A color picture of the new ESIPT fluorescent cellulose fibers, as well as the dyes in solid state, are shown in the Supplementary Information (Figure S1), and other data free of charge at http://jbcs.sbq.org.br as pdf file.

\section{Acknowledgements}

We are grateful for financial support and scholarships from the Brazilian agencies CNPq (Conselho Nacional de Desenvolvimento Científico e Tecnológico) and Fundação de Amparo à Pesquisa do Estado do Rio Grande do Sul (FAPERGS).

\section{References}

1. Blotny, G.; Tetrahedron 2006, 62, 9507

2. Blotny, G.; Tetrahedron Lett. 2003, 44, 1499.

3. Zhang, P.; Yu, Y.-D.; Zhang, Z.-H.; Synth. Commun. 2008, 38, 4474.

4. Haval, K. P.; Synlett 2006, 13, 2156.

5. Giacomelli, G.; Porcheddu, A.; De Luca, L.; Curr. Org. Chem. 2004, 8, 1497.

6. Duan, H. D.; Wang, L. Z.; Qin, D. W.; Li, X. M.; Wang, S. X.; Zhang, Y.; Synth. Commun. 2011, 41, 380.

7. Mikhaylichenko, S. N.; Patel, S. M.; Dalili, S.; Chesnyuk, A. A.; Zaplishny, V. N.; Tetrahedron Lett. 2009, 50, 2505.

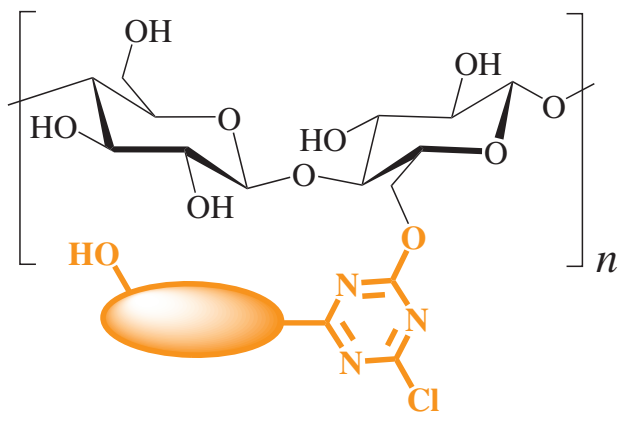

UV

radiation

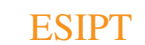

emission

8. Matloobi, M.; Schramm, H. W.; J. Heterocycl. Chem. 2010, 47, 724.

9. Courme, C.; Gresh, N.; Lenoir, C.; Vidal, M.; Garbay, C.; Florent, J. C.; Bertounesque, E.; Heterocycles 2010, 81, 867.

10. Bork, J. T.; Lee, J. W.; Khersonsky, S. M.; Moon, H. S.; Chang, Y. T.; Org. Lett. 2003, 5, 117.

11. Moral, M.; Ruiz, A.; Moreno, A.; Diaz-Ortiz, A.; Lopez-Solera, I.; de la Hoz, A.; Sanchez-Migallon, A.; Tetrahedron 2010, 66, 121.

12. Jan, J. Z.; Huang, B. H.; Lin, J.-J.; Polymer 2003, 44, 1003.

13. Ren, S. J.; Zeng, D. L.; Zhong, H. L.; Wang, Y.; Qian, S.; Fang, Q.; J. Phys. Chem. B 2010, 114, 10374.

14. Liu, B.; Qian, D. J.; Chen, M.; Wakayama, T.; Nakamura, C.; Miyake, J.; Chem. Commun. 2006, 30, 3175.

15. Zhong, H. L.; Xu, E. J.; Zeng, D. L.; Du, J. P.; Sun, J.; Ren, S. J.; Jiang, B.; Fang, Q.; Org. Lett. 2008, 10, 709.

16. Van Cott, K. E.; Amos, T.; Gibson, H. W.; Davis, R. M.; Heflin, J. R.; Dyes Pigm. 2003, 58, 145.

17. Mahler, J.; Rafler, G.; Opt. Mater. 1999, 12, 363.

18. Zhong, H. L.; Lai, H.; Fang, Q. A.; J. Phys. Chem. C 2011, 115, 2423.

19. Omer, K. M.; Ku, S. Y.; Chen, Y. C.; Wong, K. T.; Bard, A. J.; J. Am. Chem. Soc. 2010, 132, 10944.

20. Iijima, T.; Lee, C. H.; Fujiwara, Y.; Shimokawa, M.; Suzuki, H.; Yamane, K.; Yamamoto, T.; Opt. Mater. 2007, 29, 1782.

21. Cai, Y.-Q.; Wu, W.; Wang, H.; Miyake, J.; Qian, D.-J.; Surf. Sci. 2011, 605, 321.

22. Chen, H. F.; Yang, S. J.; Tsai, Z. H.; W. Y. Hung, Wang, T. C.; Wong, K. T.; J. Mater. Chem. 2009, 19, 8112.

23. Rothmann, M. M.; Haneder, S.; Da Como, E.; Lennartz, C.; Schildknecht, C.; Strohriegl, P.; Chem. Mater. 2010, 22, 2403.

24. De Hoog, P.; Gamez, P.; Driessen, W. L.; Reedijk, J.; Tetrahedron Lett. 2002, 43, 6783.

25. Gorensek, M.; Dyes Pigm. 1999, 40, 225.

26. Taylor, J. A.; Pasha, K.; Phillips, D. A. S.; Dyes Pigm. 2001, $51,145$. 
27. Um, S. I.; Lee, J. K.; Kang, Y.; Baek, D. J.; Dyes Pigm. 2006, $70,84$.

28. Son, Y. A.; Hong, J. P.; Lim, H. T.; Kim, T. K.; Dyes Pigm. 2005, 66, 231.

29. Czajkowski, W.; Paluszkiewicz, J.; Stolarski, R.; Kaźmierska, M.; Grzesiak, E.; Dyes Pigm. 2006, 71, 224.

30. Seo, J.; Kim, S.; Park, S. Y.; J. Am. Chem. Soc. 2004, 126, 11154.

31. Jung, H. S.; Kim, H. J.; Vicens, J.; Kim, J. S.; Tetrahedron Lett. 2009, 50, 983.

32. Yang, C.-C.; Tian, Y.; Chen, C.-Y.; Jen, A. K.-Y.; Chen, W.-C.; Macromol. Rapid Commun. 2007, 28, 894.

33. Wu, Y. K.; Peng, X. J.; Fan, J. L.; Gao, S.; Tian, M. Z.; Zhao, J. Z.; Sun, S.; J. Org. Chem. 2007, 72, 62.

34. Klymchenko, A. S.; Demchenko, A. P.; J. Am. Chem. Soc. 2002, 124, 12372.

35. Rodembusch, F. S.; Campo, L. F.; Rigacci, A.; Stefani, V.; J. Mater. Chem. 2005, 15, 1537.

36. Kober, U. A.; Campo, L. F.; Costa, T. M. H.; Stefani, V.; Gallas, M. R.; J. Photochem. Photobiol., A 2007, 186, 24.
37. Rodembusch, F. S.; Leusin, F. P.; Bordignon, L. B.; Gallas, M. R.; Stefani, V.; J. Photochem. Photobiol., A 2005, 153, 81.

38. Joule, J. A.; Mills, K.; Heterocyclic Chemistry, $4^{\text {th }}$ ed.; Blackwell Science: Cambridge, 2000.

39. Campo, L. F.; Corrêa, D. S.; Araújo, M. A.; Stefani, V.; Macromol. Rapid Commun. 2000, 21, 832.

40. Douhal, A.; Amat-Guerri, F.; Lillo, M. P.; Acuña, A. U.; J. Photochem. Photobiol., A 1994, 78, 127.

41. Nagaoka, S. I.; Kusunoki, J.; Fujibuchi, T.; Hatakenaka, S.; Mukai, K.; Nagashima, U.; J. Photochem. Photobiol., A 1999, 122, 151.

42. Guallar, V.; Moreno, M.; Lluch, J. M.; Amat-Guerri, F.; Douhal,A.; J. Phys. Chem. 1996, 100, 19789.

43. Santra, S.; Dogra, S. K.; Chem. Phys. 1998, 226, 285.

44. Rodembusch, F. S.; Campo, L. F.; Leusin, F. P.; Stefani, V.; J. Lumin. 2007, 126, 728.

Submitted: August 1, 2011 Published online: October 11, 2011 


\section{Synthesis, Characterization and Photophysical Properties of ESIPT Reactive Triazine Derivatives}

\section{Marcelo D. Kuplich, Fábio S. Grasel, Leandra F. Campo,} Fabiano S. Rodembusch and Valter Stefani*

Laboratório de Novos Materiais Orgânicos, Instituto de Química, Universidade Federal do Rio Grande do Sul, Av. Bento Gonçalves 9500, CP 15003, 91501-970 Porto Alegre-RS, Brazil

Picture of the dyes and stained cellulose under normal light and UV radiation

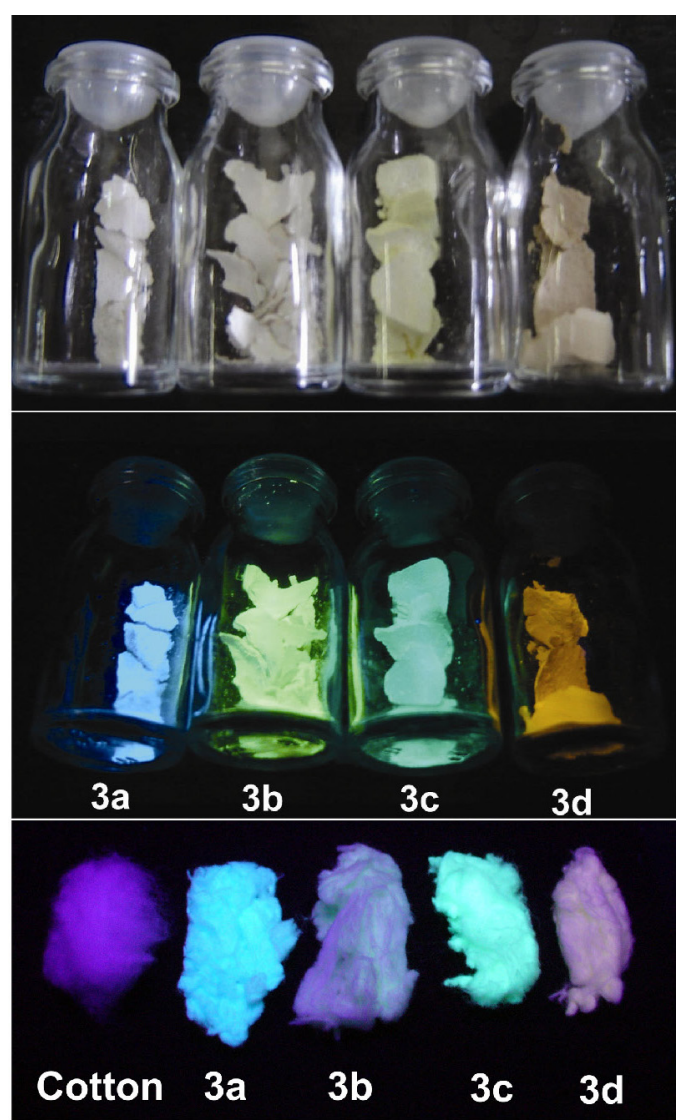

Figure S1. Triazine derivatives under normal light (top) and UV light (middle) and the respective ESIPT fluorescent cellulosic fibers under UV light (bottom).

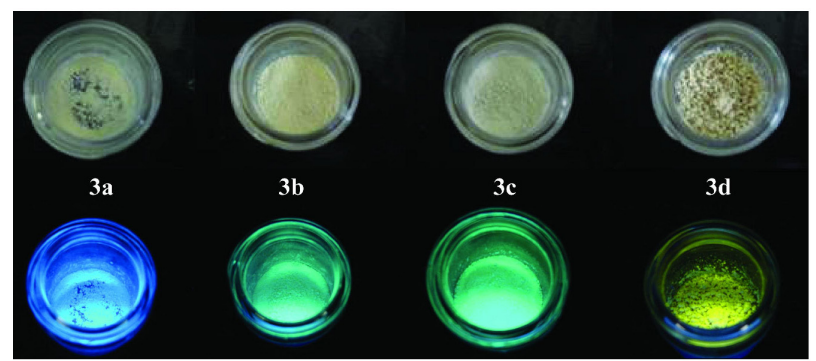

Figure S2. Triazine derivatives under normal light (top) and UV light (bottom).

Original spectroscopic data

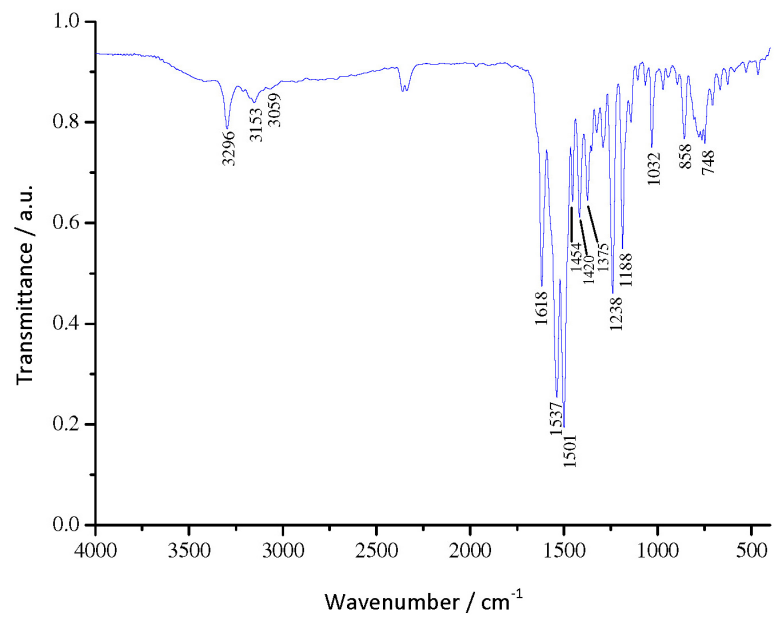

Figure S3. FTIR spectrum of the dye $\mathbf{3 a}$ in $\mathrm{KBr}$ pellets. 


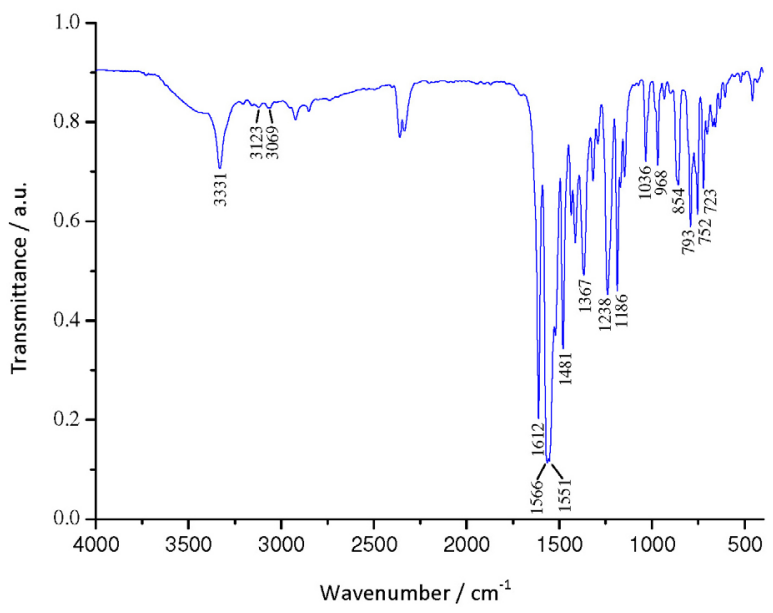

Figure S4. FTIR spectrum of the dye $\mathbf{3 b}$ in $\mathrm{KBr}$ pellets.

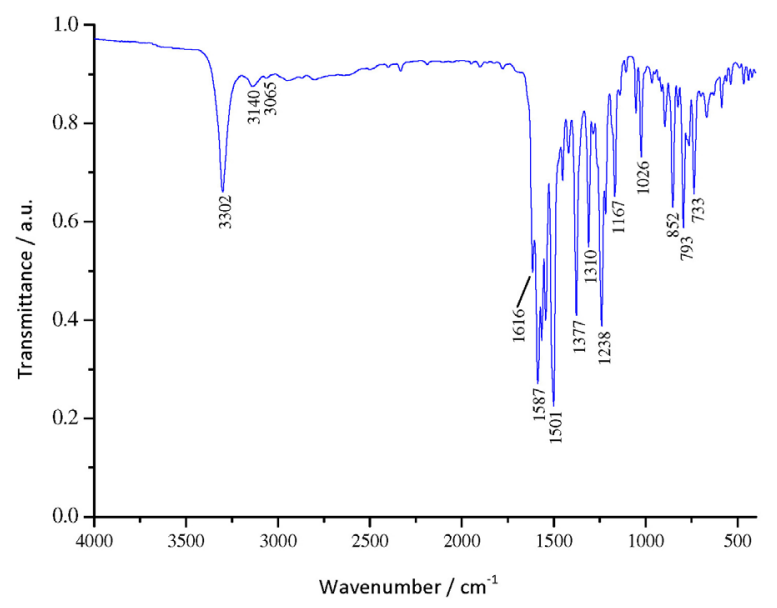

Figure S5. FTIR spectrum of the dye $\mathbf{3 c}$ in $\mathrm{KBr}$ pellets.

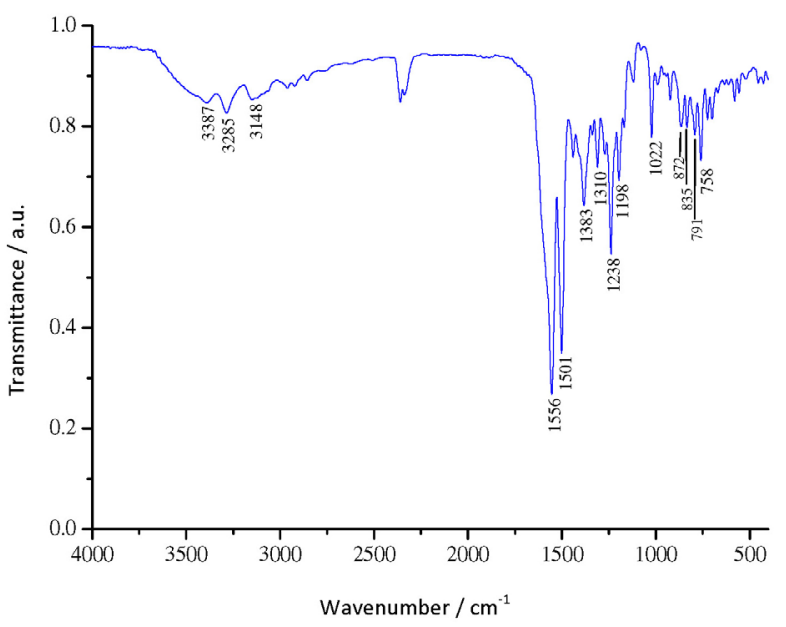

Figure S6. FTIR spectrum of the dye $\mathbf{3 d}$ in $\mathrm{KBr}$ pellets. 


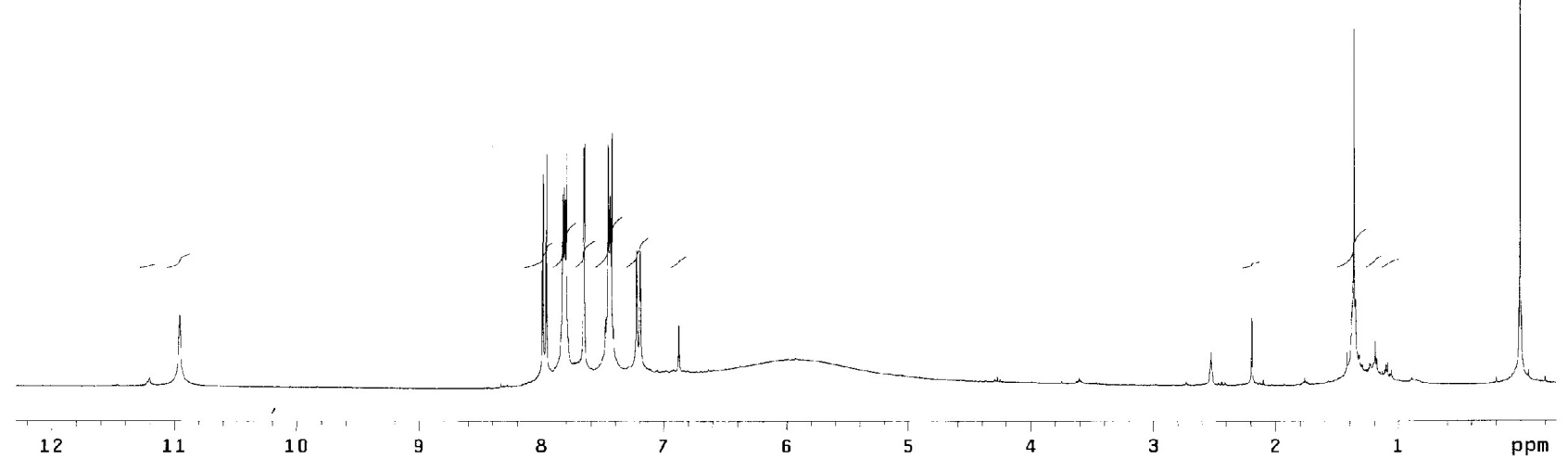

Figure S7. ${ }^{1} \mathrm{H}$ NMR spectrum of the dye $\mathbf{3 a}\left(300 \mathrm{MHz}\right.$, DMSO- $\left.d_{6}\right)$.

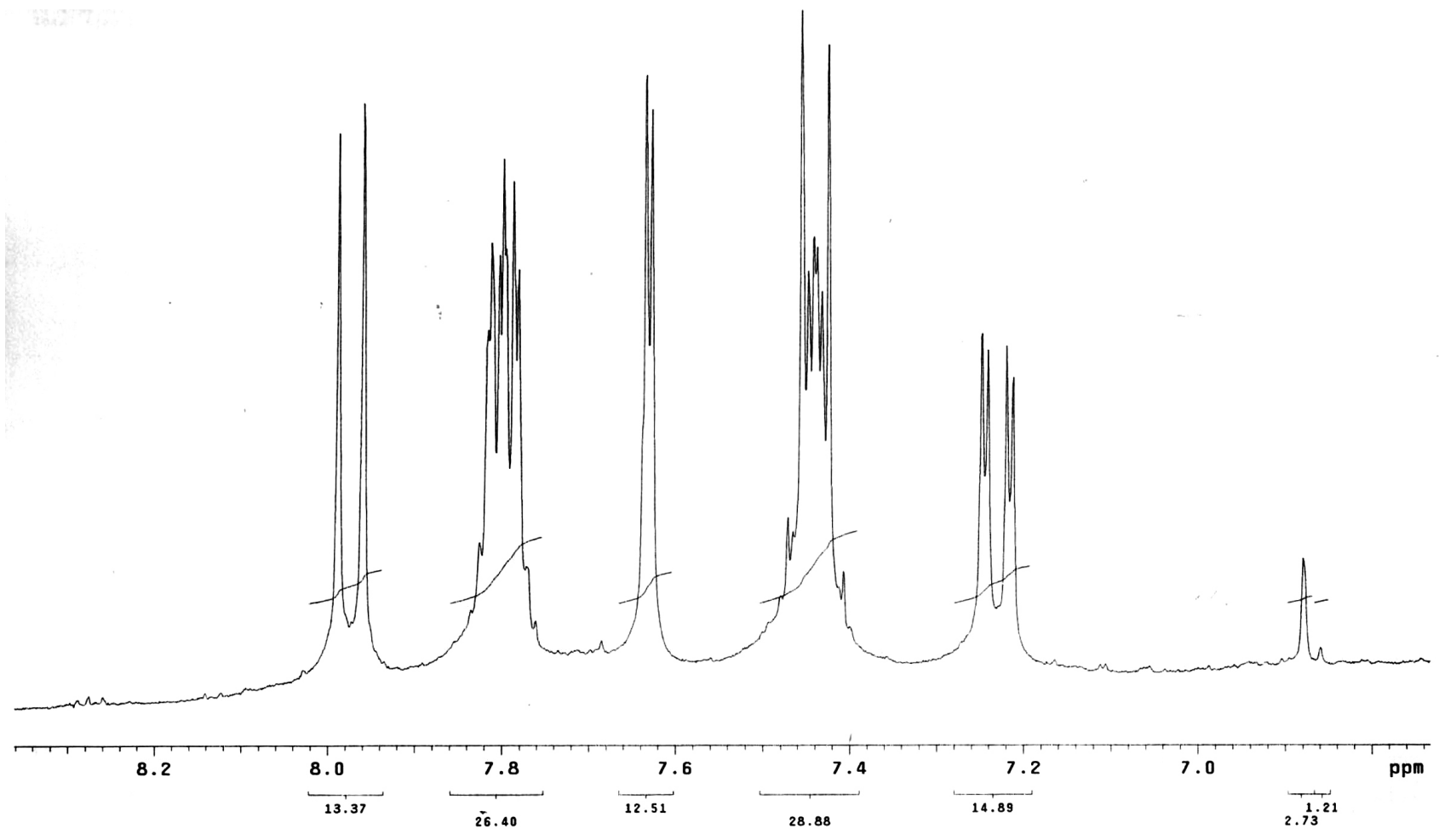

Figure S8. ${ }^{1} \mathrm{H}$ NMR spectrum of the dye $\mathbf{3 a}$ (zoom of the aromatic region). 


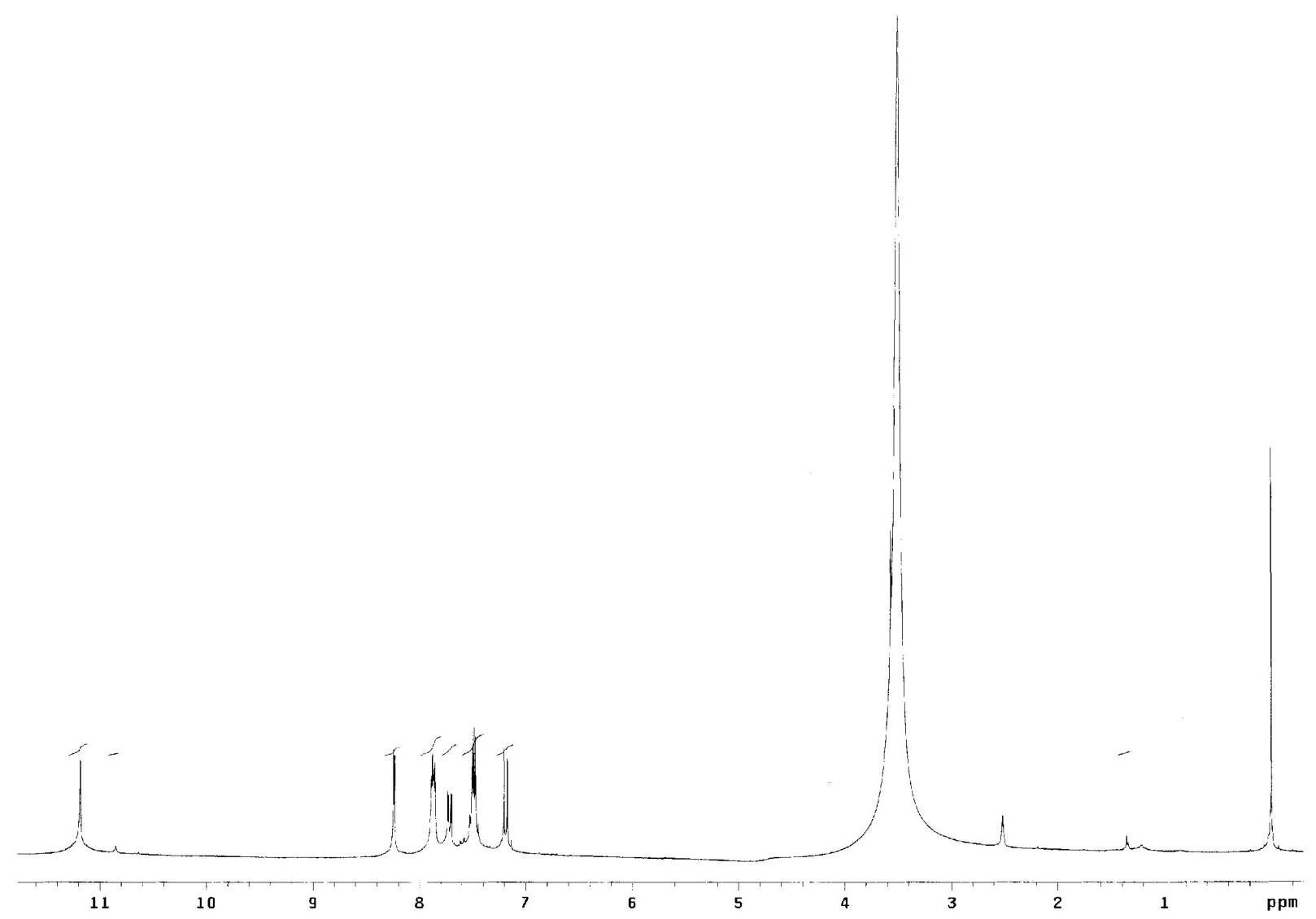

Figure S9. ${ }^{1} \mathrm{H}$ NMR spectrum of the dye $\mathbf{3 b}$ ( $300 \mathrm{MHz}$, DMSO- $d_{6}$ ).

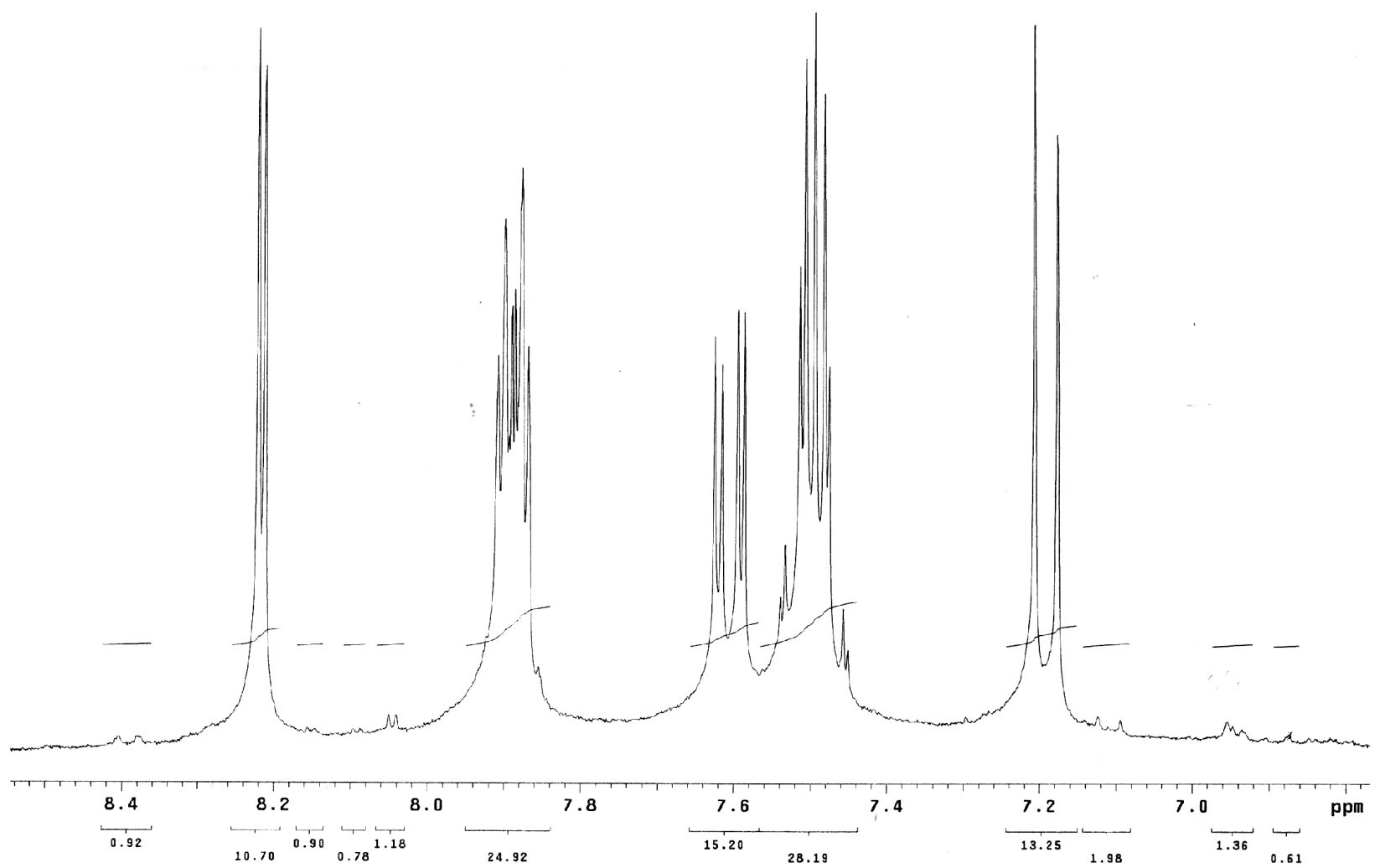

Figure S10. ${ }^{1} \mathrm{H}$ NMR spectrum of the dye $\mathbf{3 b}$ (zoom of the aromatic region). 


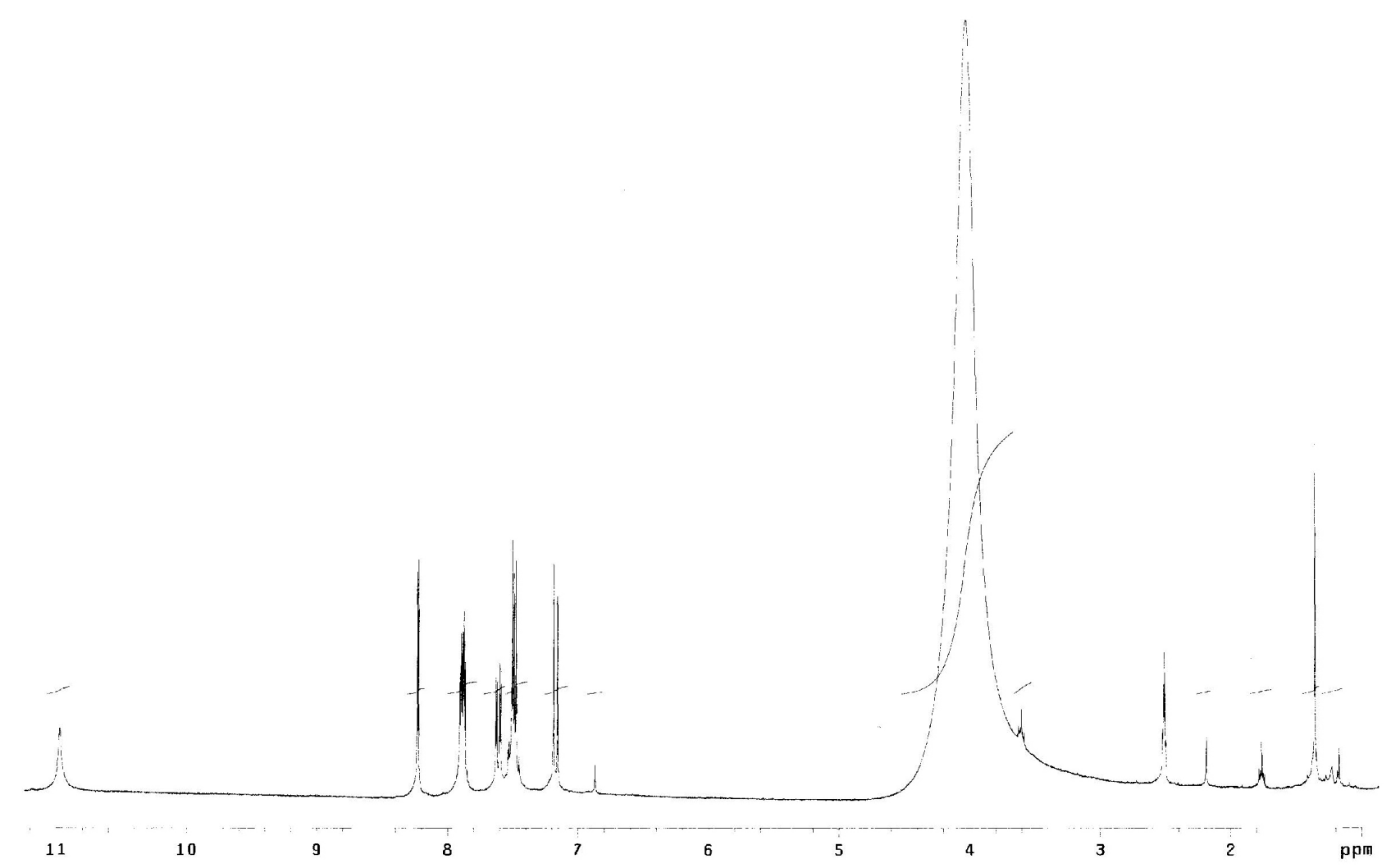

Figure S11. ${ }^{1} \mathrm{H}$ NMR spectrum of the dye $\mathbf{3 c}\left(300 \mathrm{MHz}, \mathrm{DMSO}-d_{6}\right)$.

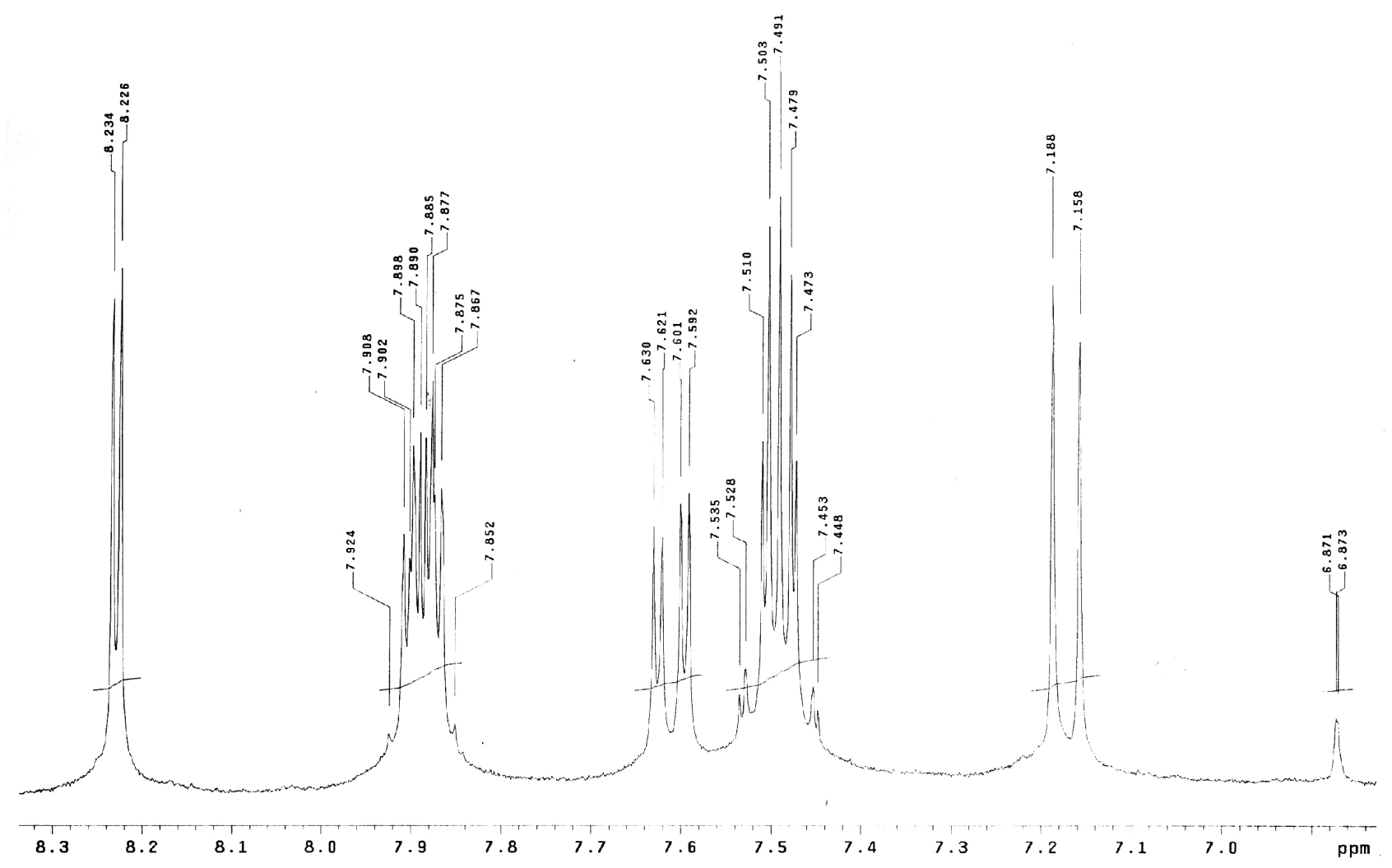

Figure S12. ${ }^{1} \mathrm{H}$ NMR spectrum of the dye $3 \mathbf{c}$ (zoom of the aromatic region). 


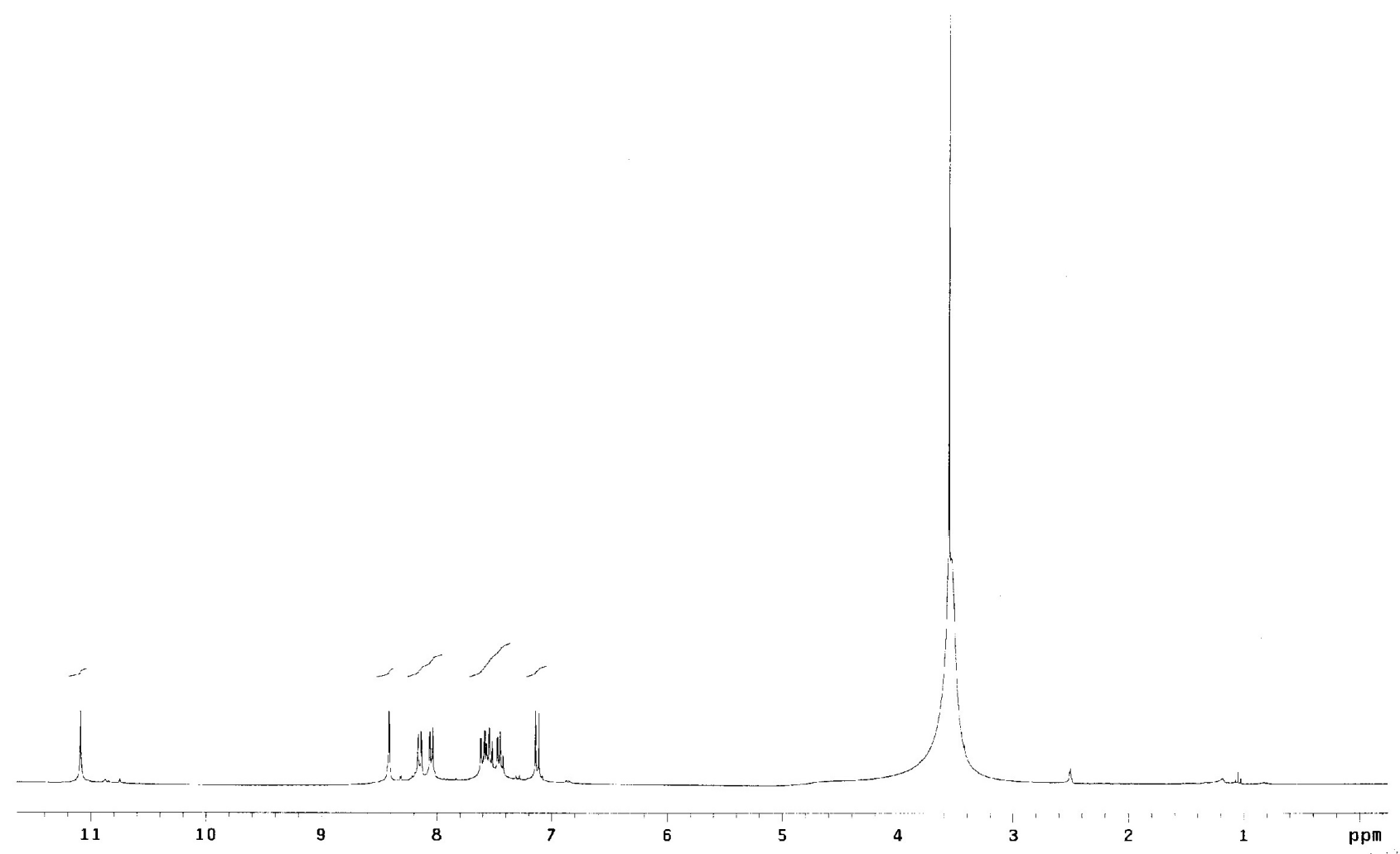

Figure S13. ${ }^{1} \mathrm{H}$ NMR spectrum of the dye $3 d$ (300 MHz, DMSO- $\left.d_{6}\right)$.

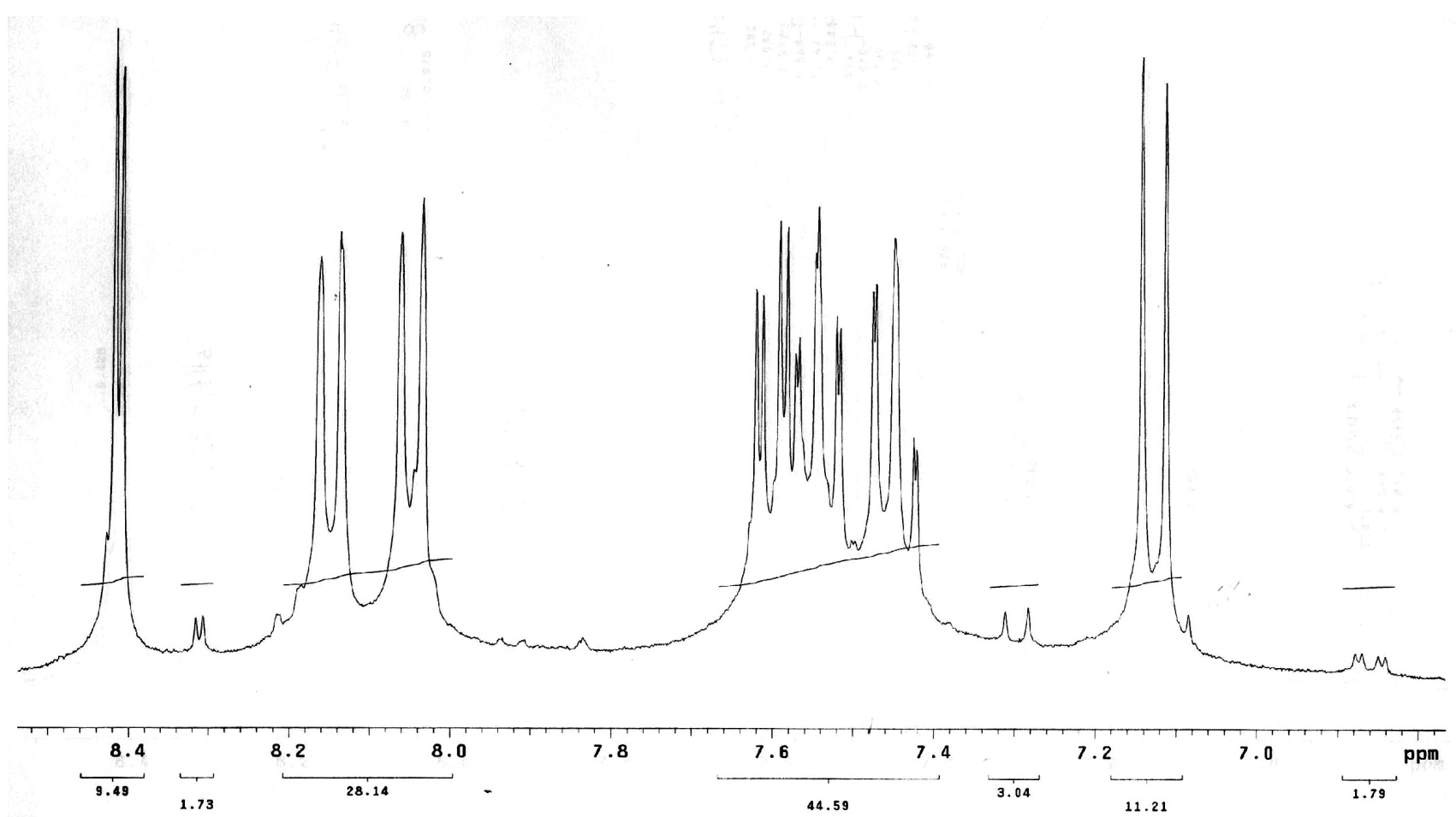

Figure S14. ${ }^{1} \mathrm{H}$ NMR spectrum of the dye $\mathbf{3 d}$ (zoom of the aromatic region). 


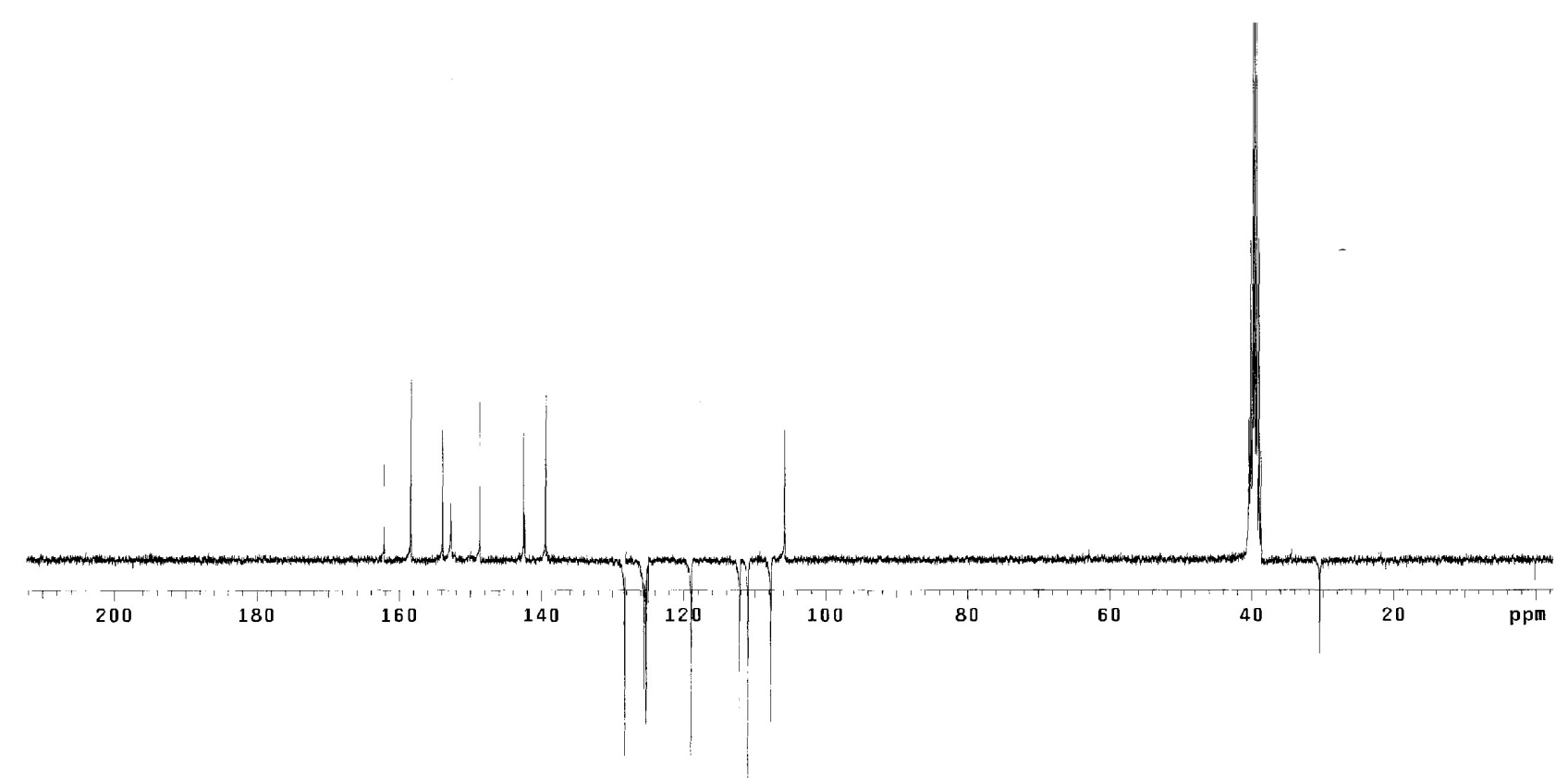

Figure S15. ${ }^{13} \mathrm{C}$ NMR (APT) spectrum of the dye 3a (75 MHz, DMSO- $\left.d_{6}\right)$.

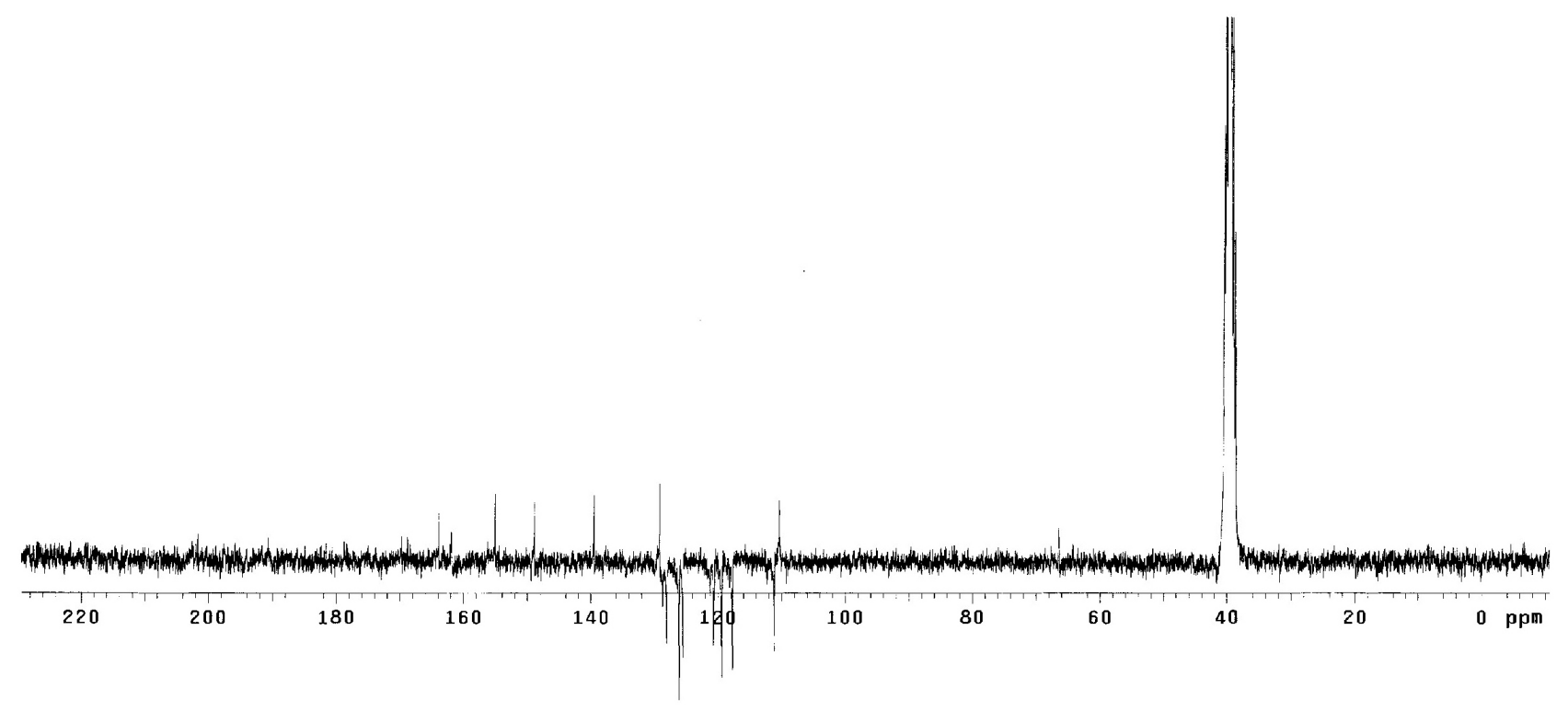

Figure S16. ${ }^{13} \mathrm{C}$ NMR (APT) spectrum of the dye $\mathbf{3 b}$ (75 MHz, DMSO- $d_{6}$ ). 


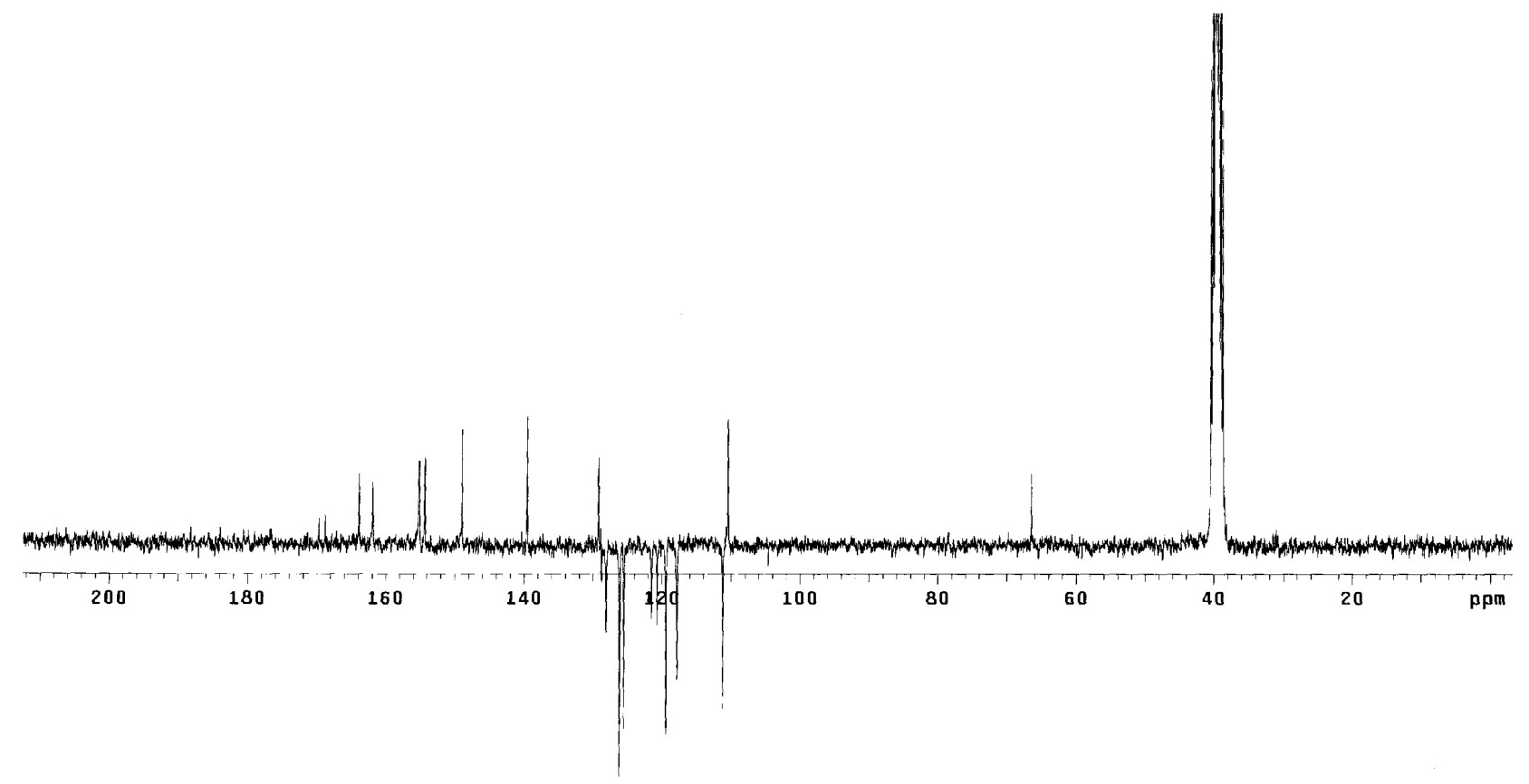

Figure S17. ${ }^{13} \mathrm{C}$ NMR (APT) spectrum of the dye $3 \mathbf{c}\left(75 \mathrm{MHz}, \mathrm{DMSO}-\mathrm{d}_{6}\right)$.

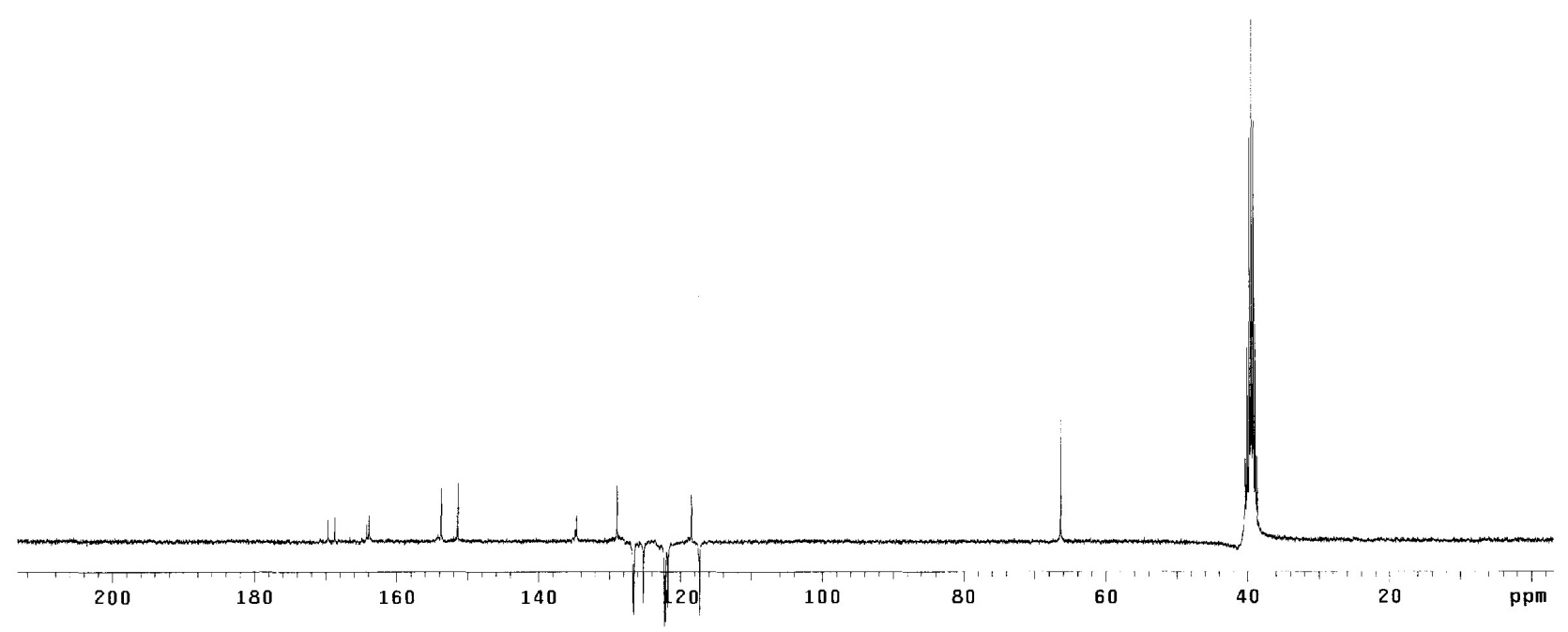

Figure S18. ${ }^{13} \mathrm{C}$ NMR (APT) spectrum of the dye 3d (75 MHz, DMSO- $d_{6}$ ). 